\title{
B lymphocytes in neuromyelitis optica
}

Jeffrey L. Bennett, MD, $\mathrm{PhD}$

Kevin C. O'Connor, PhD Amit Bar-Or, MD, FRCP Scott S. Zamvil, MD,

$\mathrm{PhD}$

Bernhard Hemmer, MD

Thomas F. Tedder, PhD

H.-Christian von Büdingen, MD

Olaf Stuve, MD, PhD

Michael R. Yeaman, PhD

Terry J. Smith, MD

Christine Stadelmann, MD

Correspondence to Dr. Bennett:

jeffrey.bennett@ucdenver.edu

Supplemental data at Neurology.org/nn

\section{ABSTRACT}

Neuromyelitis optica (NMO) is an inflammatory autoimmune disorder of the CNS that predominantly affects the spinal cord and optic nerves. A majority (approximately $75 \%$ ) of patients with NMO are seropositive for autoantibodies against the astrocyte water channel aquaporin-4 (AQP4). These autoantibodies are predominantly lgG1, and considerable evidence supports their pathogenicity, presumably by binding to AQP4 on CNS astrocytes, resulting in astrocyte injury and inflammation. Convergent clinical and laboratory-based investigations have indicated that $\mathrm{B}$ cells play a fundamental role in NMO immunopathology. Multiple mechanisms have been hypothesized: AQP4 autoantibody production, enhanced proinflammatory B cell and plasmablast activity, aberrant $\mathrm{B}$ cell tolerance checkpoints, diminished B cell regulatory function, and loss of $\mathrm{B}$ cell anergy. Accordingly, many current off-label therapies for NMO deplete B cells or modulate their activity. Understanding the role and mechanisms whereby B cells contribute to initiation, maintenance, and propagation of disease activity is important to advancing our understanding of NMO pathogenesis and developing effective disease-specific therapies. Neurol Neuroimmunol Neuroinflamm 2015;2:e104; doi: 10.1212/NXI.0000000000000104

\section{GLOSSARY}

$\mathbf{A l}_{\mathrm{AQP} 4}=\mathrm{AQP4}$ antibody index; $\mathbf{A P R I L}=$ a proliferation-inducing ligand; $\mathbf{A Q P 4}=$ aquaporin-4; $\mathbf{A S C}=$ antibody-secreting cell; BAFF = B cell-activating factor; $\mathbf{B B B}=$ blood-brain barrier; $\mathbf{B C R}=\mathrm{B}$ cell receptor; $\mathbf{B M}=$ bone marrow; $\mathbf{C R 2}=$ complement receptor 2; GM-CSF = granulocyte-macrophage colony-stimulating factor; IL = interleukin; $\mathbf{M A L T}=$ mucosaassociated lymphoid tissue; $\mathbf{M H C}=$ major histocompatibility complex; $\mathbf{M O G}=$ myelin oligodendrocyte glycoprotein; $\mathbf{M S}=$ multiple sclerosis; $\mathbf{N M O}=$ neuromyelitis optica; $\mathbf{O C B}=$ oligoclonal band; PB = peripheral blood; $\mathbf{Q I g G}=$ CSF/serum lgG quotient; RA = rheumatoid arthritis; SLE = systemic lupus erythematosus; TNF- $\alpha=$ tumor necrosis factor $\alpha$.

Neuromyelitis optica (NMO) is a rare demyelinating disorder of the CNS that is diagnosed by a combination of clinical, imaging, and laboratory criteria. ${ }^{1}$ The most common manifestations are recurrent optic neuritis and transverse myelitis; however, a broader range of cerebral, diencephalic, and brainstem syndromes are now recognized. ${ }^{2}$ Clinical and laboratory-based studies support a prominent role for $\mathrm{B}$ cells in disease pathogenesis. Autoantibodies against the aquaporin-4 (AQP4) water channel (AQP4-IgG) are detected in approximately $75 \%$ of affected individuals (reviewed in reference 3), and additional neural and non-neural autoantibodies are frequently observed in both seropositive (AQP4-IgG+) and seronegative (AQP4-IgG-) individuals. ${ }^{4}$ Both in vivo and in vitro, AQP4-IgG has been shown to reproduce cardinal features of disease pathology, ${ }^{5,6}$ supporting a direct role of this autoantibody in producing CNS injury. Plasmablasts are increased in the peripheral blood (PB) of patients with $\mathrm{NMO}$, and levels of interleukin (IL)-6, a cytokine that supports plasma cell differentiation and survival, are elevated

\footnotetext{
From the Departments of Neurology and Ophthalmology and Neuroscience Program (J.L.B.), University of Colorado, Denver; Department of Neurology (K.C.O.), Yale University School of Medicine, New Haven, CT; Neuroimmunology Unit (A.B.-O.), Montreal Neurological Institute and Hospital, McGill University, Montreal, Quebec, Canada; Department of Neurology (S.S.Z., H.-C.v.B.), UCSF School of Medicine, San Francisco, CA; Department of Neurology (B.H.), Technische Universität München, Munich Cluster for Systems Neurology (SyNergy), Munich, Germany; Department of Immunology (T.F.T.), Duke University Medical Center, Durham, NC; Departments of Neurology and Neurotherapeutics (O.S.), University of Texas Southwestern Medical Center, Dallas, TX; Department of Medicine (M.R.Y.), Divisions of Molecular Medicine and Infectious Diseases, University of California, Los Angeles; Harbor-UCLA Medical Center (M.R.Y.), Torrance, CA; Departments of Ophthalmology and Visual Sciences and Internal Medicine (T.J.S.), University of Michigan Medical School, Ann Arbor; and Institute of Neuropathology (C.S.), University Medical Center, Göttingen, Germany.

Funding information and disclosures are provided at the end of the article. Go to Neurology.org/nn for full disclosure forms. The Article Processing Charge was paid by The Guthy-Jackson Charitable Foundation.

This is an open access article distributed under the terms of the Creative Commons Attribution-Noncommercial No Derivative 4.0 License, which permits downloading and sharing the work provided it is properly cited. The work cannot be changed in any way or used commercially.
} 
in serum and CSF of both AQP4-IgG+ and AQP4-IgG - patients. $^{7}$ In addition, IL- $13^{8}$ and IL-59 also appear to be upregulated in NMO as compared with multiple sclerosis (MS). Together, these observations are consistent with a proinflammatory humoral response in NMO. Moreover, current empiric treatment regimens that reduce the frequency of disease relapses directly deplete B cells (rituximab) or have relatively selective effects on lymphocytes (azathioprine, mycophenolate mofetil, and mitoxantrone). In patients with $\mathrm{NMO}$, disease activity can be reduced without significant reduction in AQP4-IgG titers, ${ }^{10}$ suggesting that additional mechanisms, besides those associated with AQP4-IgG, may promote disease activity. In this review, we examine potential mechanisms whereby B cell dysfunction may contribute to NMO pathophysiology: increased proinflammatory B cell activity, diminished B regulatory control, plasmablast expansion and autoantibody production, loss of B cell anergy, and abnormal B cell tolerance. Although many of these mechanisms have yet to be directly implicated in NMO pathology, a critical assessment of each potential mechanism will help inform definitive investigations. Also, while it is understood that many of these mechanisms likely involve complex interactions with other components of the adaptive immune response, the focus of this review on $\mathrm{B}$ cells precludes detailed discussion of each of these contributions.

\section{B CELLS, PLASMA CELLS, PLASMABLASTS, AND} ANTIBODIES B cells can perform a wide array of normal functions that, when dysregulated, may affect NMO disease activity: antigen presentation, proinflammatory and anti-inflammatory cytokine production, and immunoglobulin production. While the role of B cells in autoimmune disorders may change during different phases of the disease, ${ }^{11}$ the apparent ability of $\mathrm{B}$ cell depletion to limit new NMO disease activity implies an overall proinflammatory role for $\mathrm{B}$ cells in $\mathrm{NMO}$, possibly due to altered numbers or abnormal activity of proinflammatory or regulatory B cell subsets (table 1). Potential mechanisms include expansion of AQP4specific plasmablast clones, failure to eliminate autoreactive B cell subsets, insufficient antigen-specific regulatory $\mathrm{B}$ cells, and/or the loss of anergic maintenance (figure 1).

Plasma cells in bone marrow (BM) and mucosaassociated lymphoid tissue (MALT) are responsible for the IgG and IgA antibodies that provide longterm humoral immunity. ${ }^{12}$ Circulating AQP4-IgG, produced by BM and/or MALT plasma cells, is presumed to initiate CNS injury after gaining access to the CNS compartment through the blood-brain barrier (BBB). ${ }^{13,14}$ The contribution of intrathecally

Table 1 Circulating human B cell populations of potential relevance in NMO

\begin{tabular}{|c|c|c|c|}
\hline Classification & Cell surface markers & Questions & References \\
\hline \multicolumn{4}{|l|}{ Naive } \\
\hline Newly emigrant & $\mathrm{CD} 19+\mathrm{CD} 27-\mathrm{CD} 10^{+} \operatorname{lgM}+$ & BM source of autoreactive B cells? & $e-1, e-2$ \\
\hline Mature & $\mathrm{CD} 19+\mathrm{CD} 27-\mathrm{CD} 10-\lg M+$ & PB source of autoreactive $B$ cells? & $e-1, e-2$ \\
\hline Mature anergic & $\mathrm{CD}_{19}+\lg \mathrm{D}^{+} \mathrm{CD} 21^{-} \mathrm{CD} 27-\lg \mathrm{M}^{\mathrm{low}}$ & Pool of silenced autoreactive B cells? & e-3 \\
\hline \multicolumn{4}{|l|}{ Transitional } \\
\hline $\mathrm{T} 1$ & $\mathrm{CD} 19^{+} \mathrm{CD} 24^{\text {high }} \mathrm{CD} 38^{\text {high }} \lg \mathrm{M}^{\text {hil }} \lg \mathrm{D}^{\text {lo }}$ & CD27- B10 regulatory population? & e-4 \\
\hline T2 & $\mathrm{CD}_{19}{ }^{+} \mathrm{CD} 24^{\text {int }} \mathrm{CD} 38^{\text {int }} \lg M^{\text {int }} \operatorname{lgD}+$ & CD27- B10 regulatory population? & $e-4$ \\
\hline тз & $\mathrm{CD} 19+\mathrm{CD} 24^{\text {int }} \mathrm{CD} 38^{\text {int }} \mathrm{gM}^{10} \mathrm{lgD}+$ & Anergic subset? & $e-5$ \\
\hline \multicolumn{4}{|l|}{ Memory } \\
\hline Unswitched & $\mathrm{CD} 19+\mathrm{CD} 27+\lg \mathrm{D}+\lg \mathrm{M}+$ & $\begin{array}{l}\text { IgD+ autoreactive } B \text { cells? Source of } C D 24^{+} \\
\text {regulatory B10 subset? }\end{array}$ & $e-6, e-7$ \\
\hline Switched & $\mathrm{CD} 19+\mathrm{CD} 27+\lg D-\lg M-$ & Source of APCs or proinflammatory B cells? & $e-8, e-9$ \\
\hline Double-negative & $\mathrm{CD} 19^{+} \mathrm{CD} 27-\lg \mathrm{-}-$ & Source of APCs or proinflammatory B cells? & $e-10$ \\
\hline Plasmablasts & $\mathrm{CD}_{19}{ }^{+} \mathrm{CD} 2 \mathrm{O}^{-} \mathrm{CD} 38^{+}$ & $\begin{array}{l}\text { Production of immunoglobulin? Induction of } \\
\text { regulatory cells? Induction } \\
\text { of proinflammatory B cells? }\end{array}$ & $e-11, e-12$ \\
\hline
\end{tabular}

Abbreviations: $\mathrm{APC}=$ antigen-presenting cell; $\mathrm{BM}=$ bone marrow; $\mathrm{NMO}=$ neuromyelitis optica; $\mathrm{PB}=$ peripheral blood. This list represents widely accepted minimal marker combinations but is not meant to be exhaustive.

References e-1-e-12 are available at Neurology.org/nn. 


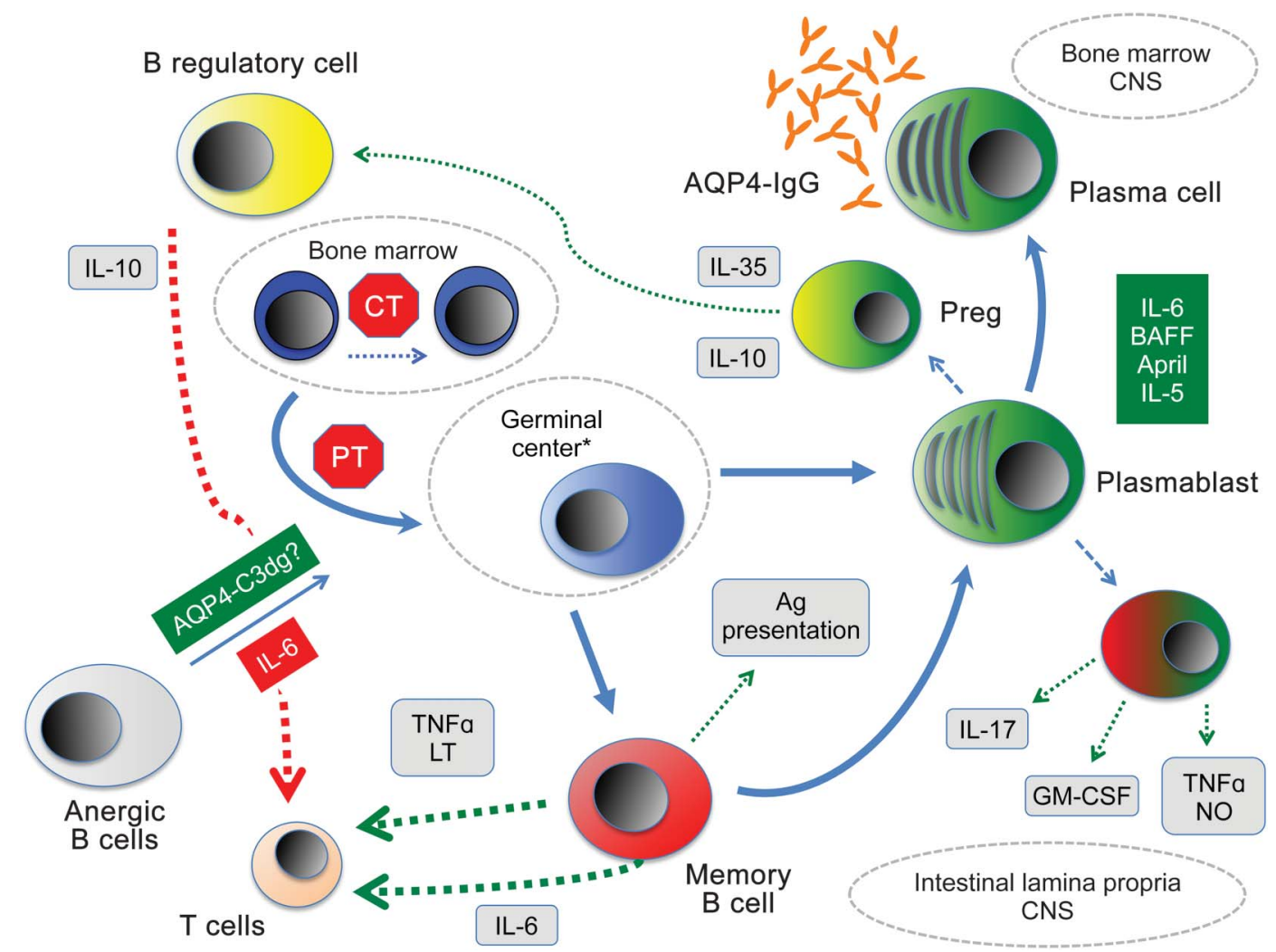

B cells may play proinflammatory and anti-inflammatory roles in neuromyelitis optica pathogenesis through various mechanisms. Autoreactive B cells may be generated by defective central tolerance (CT; primary checkpoint in bone marrow) or peripheral tolerance (PT; secondary checkpoint in secondary lymphoid tissue). Stimulated B cells leaving germinal centers may differentiate into memory B cells or antibody-producing plasmablasts and plasma cells. In addition to the production of aquaporin-4 (AQP4)-IgG in the bone marrow and CNS, plasma cells and plasmablasts may have additional proinflammatory and anti-inflammatory functions. Plasmablasts may secrete factors such as interleukin (IL)-17, tumor necrosis factor $\alpha$ (TNF- $\alpha$ )/nitrous oxide (NO), and granulocyte-macrophage colony-stimulating factor (GM-CSF), facilitating neutrophil and macrophage CNS infiltration and heightening proinflammatory immune cell activity through modulation of gut microbiota. Alternatively, anti-inflammatory plasma cells (Pregs) may suppress disease activity in part through the production of IL-10 or IL-35. Memory B cells may further promote disease activity by antigen (Ag) presentation, secretion of the proinflammatory cytokines lymphotoxin (LT) and TNF- $\alpha$, or facilitation of Th17 differentiation (IL-6 production). IL-10-producing B regulatory cells may limit the immune response through antigen-specific or bystander suppression of proinflammatory $T$ cell function. Circulating AQP4-specific anergic B cells may provide a pool of autoreactive disease-relevant B cells that contribute to disease activity. The pool of anergic $B$ cells may be enhanced by deficient $B$ cell tolerance; release of anergic $B$ cells may be enhanced by antigen-complement adducts or decreased levels of IL-6. The location of germinal centers producing AQP4-reactive memory cells and plasmablasts remains unknown (asterisk). Blue arrows: developmental pathways; dashed green arrows and boxes: stimulatory cytokines; dashed red arrows and boxes: inhibitory cytokines. APRIL $=a$ proliferation-inducing ligand; BAFF = B cell-activating factor.

produced AQP4-IgG to the pool of pathogenic CNS antibody remains less clear. Plasmablasts are elevated in the CSF of patients with NMO during relapse, ${ }^{5,15}$ and limited NMO cases have shown AQP4-IgG restricted to the CSF. ${ }^{16}$ In contrast, measures of intrathecal IgG synthesis, such as CSF-restricted oligoclonal IgG bands (OCBs), elevated CSF/serum IgG quotient $(\mathrm{QIgG})$, or positive AQP4 antibody index $\left(\mathrm{AI}_{\mathrm{AQP} 4}\right)$, are observed in only $16.4 \%, 8 \%$, and $4.3 \%$ of patients with NMO, respectively. ${ }^{13,14}$ These discrepancies may arise in part from technical differences; clonally expanded AQP4-specific CSF plasmablasts are detected using flow cytometry and single-cell PCR, whereas $\mathrm{QIgG}, \mathrm{AI}_{\mathrm{AQP} 4}$, and $\mathrm{OCBs}$ are measured using nephelometric, immunofluorescence, and electrophoretic techniques. These latter methods may be less sensitive in detecting intrathecal immunoglobulin production during active disease when the BBB is dysfunctional. Furthermore, the level of intrathecal AQP4-IgG synthesis could be significantly underestimated due to tissue binding of AQP4-IgG.

Newly generated plasmablasts circulating in the $\mathrm{PB}$ of patients with NMO are likely precursors for antibody-producing plasma cells that reside in the $\mathrm{BM}$ and CNS. ${ }^{17}$ Chihara et al. ${ }^{18}$ have identified a 
$\mathrm{CD} 19^{\text {int }} \mathrm{CD} 27^{\text {high }} \mathrm{CD} 38^{\text {high }} \mathrm{CD} 180^{-} \mathrm{B}$ cell population that is selectively increased in NMO PB. These cells have phenotypic features of plasmablasts, secrete increased AQP4-IgG following IL-6 stimulation in vitro, and overlap with a similarly defined CSF B cell population. ${ }^{15,18}$ These PB plasmablasts may not only repopulate or replenish BM plasma cell niches but also deliver antibody-secreting cells (ASCs) to the CNS compartment. In addition, subsets of plasma cells may exacerbate or mitigate disease activity through the secretion of proinflammatory or regulatory cytokines (discussed below). ${ }^{19}$

The initial molecular characterization of the humoral immune response in an early AQP4-IgG+ NMO patient revealed a clonally expanded plasmablast population primarily directed against AQP4. ${ }^{5}$ In contrast to similar analyses in $\mathrm{MS},{ }^{20}$ the repertoire showed significant intraclonal variability and heavy chain variable regions dominated by $\mathrm{VH} 2$ rather than VH4 gene segments. ${ }^{20,21}$ These findings provide a molecular signature suggesting that the CNS B cell population in NMO may emanate from recent germinal center activity that is driven by antigenic targets that are distinct from those in MS. Further analyses of the B cell repertoires in AQP4-IgG+ and AQP4IgG - NMO could help to distinguish ASCs in these two disease subsets and provide an avenue for differentiating NMO from other inflammatory demyelinating disorders. A limited analysis of $\mathrm{PB}$ plasmablasts and CSF B cells from the same patient has suggested that circulating plasmablasts may migrate between these compartments during disease activity. ${ }^{15}$ Given the results of similar studies in MS, a comprehensive analysis of peripheral and CSF B cell repertoires using high-throughput deep sequencing might clarify the patterns of $\mathrm{B}$ cell migration in NMO. ${ }^{21}$

The variability of AQP4-IgG titers in treated patients $^{22}$ and of CSF AQP4-IgG titers and plasma cells during disease relapse ${ }^{13}$ suggest that AQP4-specific ASCs are a labile population that may be modulated at the levels of production, trafficking, and maintenance. IL-5, IL-6, tumor necrosis factor $\alpha$ (TNF- $\alpha$ ), $B$ cell-activating factor (BAFF), and a proliferationinducing ligand (APRIL) are critical for isolated plasma cell survival in vitro (table 2). ${ }^{23}$ Elevated CSF levels of IL-6, BAFF, APRIL, and IL-5 likely play a role in facilitating AQP4-specific ASC survival in the CNS of patients with NMO., ${ }^{7,9}$ In BM, eosinophils are the main source of APRIL and IL-6, which are essential for the support of plasma cell niches. ${ }^{24}$ Likewise, CNS infiltration of eosinophils may facilitate plasma cell survival and IgG production in NMO lesions. Modulation of eosinophil number and location or direct targeting of IL-6 signaling may have a direct effect on plasma cell survival, autoantibody production, and NMO pathology. For example, the S1P1 receptor agonist fingolimod promotes retention of eosinophils in BM and ASCs in secondary

Table 2 B cell cytokines implicated in NMO

\begin{tabular}{|c|c|c|}
\hline Cytokine & Levels in NMO & NMO relevant source(s) \\
\hline IL-6 & $\begin{array}{l}\text { Increased serum } \\
\text { Increased CSF }\end{array}$ & $\begin{array}{l}\text { Lymphocytes; monocytes and macrophages; endothelial cells; } \\
\text { granulocytes; glial cells }\end{array}$ \\
\hline IL-5 & Unchanged CSF & T cells; eosinophils; mast cells; astrocytes \\
\hline $\begin{array}{l}\text { BAFF (B)/ } \\
\text { APRIL (A) }\end{array}$ & $\begin{array}{l}\text { (B) Increased serum } \\
\text { (B) Increased CSF } \\
\text { (A) Increased serum }\end{array}$ & $\begin{array}{l}\text { B cells }(A / B) ; \text { activated T cells }(A / B) ; \text { astrocytes }(B) ; \text { microglia }(B) ; \\
\text { NK cells }(B) ; \text { neutrophils }(A / B) ; \text { monocytes and macrophages }(A / B) \\
\text { dendritic cells }(A / B) ; \text { intestinal epithelial cells }(B)\end{array}$ \\
\hline IL-10 & $\begin{array}{l}\text { Decreased serum } \\
\text { Increased CSF }\end{array}$ & B10 regulatory cells; plasmablasts; plasma cells \\
\hline IL-35 & ND & Plasmablasts; plasma cells \\
\hline TNF- $\alpha$ & $\begin{array}{l}+ \text { I- Increased CSF } \\
\text { Decreased serum }\end{array}$ & B cells; plasma cells; microglia; monocytes \\
\hline IL-17 & $\begin{array}{l}\text { Increased serum } \\
\text { Increased CSF }\end{array}$ & Plasma cells; T cells \\
\hline GM-CSF & Unchanged CSF & Plasmablasts; plasma cells; T cells; dendritic cells \\
\hline Nitric oxide & ND & Plasma cells; microglia \\
\hline
\end{tabular}

\begin{tabular}{|c|c|}
\hline Potential action & References \\
\hline $\begin{array}{l}\text { Support plasmablast and plasma cell } \\
\text { differentiation and survival; promote Th17 } \\
\text { differentiation }\end{array}$ & $e-13-e-19$ \\
\hline $\begin{array}{l}\text { Maintenance of plasma cell niches and } \\
\text { CNS antibody-secreting cells }\end{array}$ & $\begin{array}{l}\text { e-13, e-16, } \\
\text { e-18-e-20 }\end{array}$ \\
\hline Plasmablast and plasma cell survival & $e-21-e-24$ \\
\hline $\begin{array}{l}\text { Memory B regulatory cell function; plasma } \\
\text { cell regulatory function }\end{array}$ & $\begin{array}{l}\text { e-14, e-18, } \\
\text { e-19, e-25, } \\
\text { e-29 }\end{array}$ \\
\hline $\begin{array}{l}\text { Induction of B10 regulatory cells; facilitate } \\
\mathrm{T} \text { regulatory cell function }\end{array}$ & $e-25, e-27$ \\
\hline $\begin{array}{l}\text { Proinflammatory B cell activity; increase } \\
\text { IgA secretion; influence gut microbiota }\end{array}$ & $\begin{array}{l}e-14, e-18 \\
e-19, e-28- \\
e-30\end{array}$ \\
\hline $\begin{array}{l}\text { Proinflammatory T cell activity; neutrophil } \\
\text { recruitment; enhanced B cell survival }\end{array}$ & $\begin{array}{l}\text { e-14, e-18, } \\
\text { e-19, e-31- } \\
\text { e-33 }\end{array}$ \\
\hline Neutrophil recruitment & $\begin{array}{l}e-14, e-19 \\
e-34\end{array}$ \\
\hline $\begin{array}{l}\text { Increase serum IgA/lgA-secreting plasma } \\
\text { cells; influence gut microbiota }\end{array}$ & e-29 \\
\hline
\end{tabular}

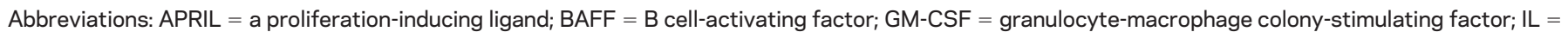
interleukin; ND = not determined; NK = natural killer; NMO = neuromyelitis optica; TNF- $\alpha=$ tumor necrosis factor $\alpha$.

$+I-=$ contradictory results. References e-13-e-34 are available at Neurology.org/nn. 
lymphoid tissue. ${ }^{25,26}$ This effect could result in enhanced serum AQP4-IgG titers and CNS ASC migration, resulting in the exacerbation of NMO disease activity reported with fingolimod treatment. ${ }^{27} \mathrm{It}$ is interesting that natalizumab, another MS therapy noted to exacerbate NMO disease activity and tissue injury, ${ }^{28,29}$ increases circulating eosinophils ${ }^{30,31}$ that may contribute directly to lesion formation ${ }^{32}$ or support local ASCs. In contrast, inhibition of IL-6 signaling using the anti-IL-6 receptor monoclonal antibody tocilizumab reduces $\mathrm{PB}$ plasmablasts and AQP4-IgG titers in some patients and appears to reduce relapse activity in patients with NMO. ${ }^{33}$ These observations are consistent with a role for IL-6 in the induction of plasma cells that produce autoantibodies against AQP4 and other relevant antigens. $^{23}$

While some studies have reported a correlation between AQP4-IgG titers and clinical relapse, a consistent relationship with disease activity has yet to emerge. ${ }^{22,34}$ A threshold level of AQP4-IgG that triggers clinical relapse, even in a given individual, has not been identified, and serum levels during relapse differ widely within and between individuals. Moreover, failure of rituximab has been documented in some patients with $\mathrm{NMO}$ experiencing relapses despite undetectable $\mathrm{CD} 19^{+}$cells in $\mathrm{PB}$ and high levels of AQP4-IgG serum titers. ${ }^{35}$ In one study, treatment with anti-CD20 antibody (rituximab) appeared to result in a rapid and transient increase in serum AQP4-IgG titers and clinical relapse in tandem with increased circulating BAFF levels ${ }^{36}$; however, in another study, successful anti-CD20 therapy did not result in reduced levels of AQP4-IgG, BAFF, or APRIL. ${ }^{10}$ Discordance between AQP4-IgG serum titers and disease activity may also be explained by compartmental localization at the site of tissue damage in the CNS. In addition, antibodies may differ with respect to affinity during the course of disease. These changes may be undetectable in current assays. Indeed, in patients with NMO, CSF AQP4-IgG titers have been observed to correlate more closely with clinical activity and neuroinflammation than serum titers. $^{37}$ Alternatively, antibodies targeted against other self-antigens may contribute to disease activity. For instance, autoantibodies against myelin oligodendrocyte glycoprotein (MOG) have been detected in a small fraction of patients diagnosed with $\mathrm{NMO}$ who are AQP4-IgG-. There are also clinical differences between the MOG-IgG+ and AQP4$\mathrm{IgG}+\mathrm{NMO}$ patients, although the findings are based on small numbers of patients and require further study. ${ }^{38,39}$ Unlike anti-AQP4-IgG, anti-MOGIgG injected intracerebrally into murine brain with human complement does not reproduce NMO pathology. ${ }^{40}$
PROINFLAMMATORY B CELLS IN NMO B cells may facilitate disease activity in NMO by stimulating pathogenic $\mathrm{T}$ cell responses through antigen presentation or cytokine secretion (table 2). B cells express major histocompatibility complex (MHC) class II molecules constitutively and serve as potent antigen-presenting cells. ${ }^{41} \mathrm{~B}$ cell MHC II expression also contributes to the development of $\mathrm{T}$ follicular helper cells that participate in $\mathrm{B}$ cell differentiation and immunoglobulin isotype switching. ${ }^{41,42}$ Thus, cooperation between AQP4-specific B cells and AQP4-specific T cells may be particularly important in ASC differentiation and the production of NMOIgG. Moreover, the presence of AQP4-specific B cells may promote $\mathrm{T}$ cell responses against AQP4 that contribute to tissue damage. $\mathrm{B}$ cells may produce proinflammatory cytokines through antigen-specific or polyclonal stimulation. IL-6 secretion by proinflammatory memory $\mathrm{B}$ cells in NMO may aggravate disease activity by promoting pathogenic Th17 differentiation. Indeed, during NMO exacerbations, IL-17A and IL-23 are elevated, indicating enhanced Th17 pathway activity. ${ }^{43} \mathrm{~A}$ reduction in IL-6 secretion following anti-CD20 $\mathrm{B}$ cell depletion in patients with NMO may explain some of the discordance between relapse activity reduction and persistently elevated AQP4-IgG titers. Reduced Th17 pathway activity resulting from reduction in the number of proinflammatory $\mathrm{CD}^{+} 0^{+}$memory $\mathrm{B}$ cells may significantly reduce clinical activity despite a minimal effect on AQP4IgG production by $\mathrm{CD}^{-} 0^{-}$tissue-resident plasma cells. In addition, alterations in the cytokine profile of $\mathrm{B}$ cells that reconstitute after rituximab treatment may explain some benefits of treatment. In MS, B cells emerging after anti-CD20 depletion secrete lower levels of IL-6. ${ }^{44}$ Also, reconstituting B cells may have a reduced proinflammatory cytokine profile, with lower secretion of lymphotoxin or TNF- $\alpha$ upon activation. ${ }^{45}$

Bystander activation may also result in the production of B cell cytokines that promote NMO disease activity. Cytokines, such as TNF- $\alpha$, IL-17, and granulocyte-macrophage colony-stimulating factor (GM-CSF), may be produced by various plasma cell subsets and regulate humoral immunity, alter interactions with commensal microbiota, and modify adaptive and innate immune responses. Nitric oxide and TNF- $\alpha$ secreted by plasma cells in the lamina propria of the small intestine modulate IgA secretion and can alter the composition of the gut flora. ${ }^{46}$ Given that AQP4-specific T cell responses in NMO display cross-reactivity to Clostridium perfringens adenosine triphosphate-binding cassette transporter permease in vitro, ${ }^{47}$ such changes in commensal microbiota may be able to influence downstream $\mathrm{T}$ cell reactivity. 
During bacterial and parasitic infections, plasma cells are a source of GM-CSF and IL-17. ${ }^{48,49}$ Thus, in the context of NMO, increased levels of GM-CSF and IL-17 may result in increased granulocyte recruitment to the CNS, promoting disease relapse. Future studies are needed to directly determine the quantity, phenotype, and activity of proinflammatory $\mathrm{B}$ cells and ASCs in NMO and NMO spectrum diseases.

REGULATORY B CELLS IN NMO Ongoing advances in the understanding of $\mathrm{B}$ cell contributions to autoimmunity include the elucidation of a population of $\mathrm{B}$ cells that can negatively regulate cellular immune responses and inflammation, the most studied of which are those secreting IL-10, termed B10 cells (tables 1 and 2). ${ }^{50}$ Recently, IL-35, which is essential for the immunosuppressive function of $\mathrm{T}$ regulatory cells, ${ }^{51}$ was also noted to be necessary for the suppressive function of $\mathrm{B}$ cells. ${ }^{52}$ Mice lacking IL-35 in their B cells only were unable to recover from experimental autoimmune encephalomyelitis and had higher macrophage and inflammatory $\mathrm{T}$ cell activity. IL-35 was also found to be critical for the induction of $\mathrm{B}$ regulatory cells..$^{53}$ It is interesting that in both infectious and autoimmune models, the major B cell sources of IL-10 and IL-35 transcripts were plasmablasts and plasma cells, ${ }^{52}$ suggesting that mature plasma cells expressing IL-35 may be important for the maintenance of $\mathrm{B}$ regulatory cell numbers. Additional studies will be needed to confirm plasmablast IL-10 expression, the extent to which such expression may be antigenrestricted, and whether this expression profile is evident during human plasma cell development.

Human B cells with similar features to murine B10 cells have been identified and are expanded in several human autoimmune disorders, including systemic lupus erythematosus (SLE), rheumatoid arthritis (RA), Sjögren syndrome, and bullous skin disease. ${ }^{54}$ Human B10 regulatory B cells may play an important role in suppressing AQP4-specific and innate immune responses in NMO (figure 1). Quan et al. ${ }^{55}$ noted both fewer $\mathrm{B} 10$ regulatory cells $\left(\mathrm{CD} 19^{+} \mathrm{CD} 24^{\text {high }} \mathrm{CD} 38^{\text {high }}\right)$ in relapsing $\mathrm{AQP} 4+$ NMO patients and reduced IL-10 induction following in vitro stimulation of $\mathrm{CD} 19^{+} \mathrm{B}$ cells. The study, however, may have underestimated the circulating $\mathrm{B} 10$ population, as regulatory $\mathrm{B} 10$ cells do not have clearly defined cell differentiation markers, and the expression of CD38 $8^{\text {high }}$ may be unreliable for identifying circulating B regulatory cells. ${ }^{54}$ It is interesting that a reduction in IL-10 expression by $\mathrm{CD} 19^{+} \mathrm{B}$ cells has been observed in patients with $\mathrm{MS},{ }^{56}$ and the beneficial effect of parasitic infection in patients with MS has been associated with an increased production of B cell-derived IL-10. ${ }^{57}$ Therefore, the possibility that B cells play an important role in suppressing immune activation in NMO warrants further investigation.

B CELL TOLERANCE AND NMO PATHOGENESIS: CENTRAL AND PERIPHERAL TOLERANCE AND B CELL ANERGY Central and peripheral tolerance. During early B cell development, immunoglobulin variable region gene segments are stochastically recombined to generate functional antibodies (B cell receptors [BCRs]) that are expressed on the cell surface. This process is fundamental for the generation of the wide diversity of the immunoglobulin repertoire but also generates autoreactive B cells alongside those that comprise the nonself-reactive naive repertoire. Elimination of autoreactive B cells is controlled by tolerance mechanisms. The majority of autoreactive B cells are eliminated at 2 separate steps ${ }^{58}$ during B cell development (figure 2). A central checkpoint in the BM between early immature and immature B cell stages removes a large population of developing B cells that express autoreactive and polyreactive antibodies. These antibodies have been shown to display low-level reactivity to multiple self-antigens by in vitro approaches. After passing through the first checkpoint, only a small fraction of B cell clones with low levels of self-reactivity migrate to the periphery. ${ }^{59}$ The second B cell tolerance checkpoint selects against these autoreactive newly emigrant $\mathrm{B}$ cells before they enter the mature naïve $\mathrm{B}$ cell compartment.

The mechanisms underlying tolerance defects in autoimmune diseases have not been fully elucidated. Central tolerance checkpoint integrity is thought to be associated with $\mathrm{B}$ cell-inherent characteristics. These mechanisms are specifically associated with signaling through the BCR. ${ }^{60}$ Conversely, the peripheral tolerance checkpoint is thought to be dependent on T cell/ $\mathrm{B}$ cell interactions, particularly those involving regulatory $\mathrm{T}$ cells, rather than $\mathrm{B}$ cell-inherent characteristics. ${ }^{61}$ Dysregulation of central or peripheral B cell tolerance may be measured by evaluating the frequency of autoreactive $\mathrm{B}$ cells in the naive repertoire. ${ }^{59} \mathrm{~B}$ cell tolerance defects have been clearly demonstrated in a number of autoimmune diseases. For example, patients with RA, SLE, and type 1 diabetes exhibit defects in both central and peripheral B cell tolerance checkpoints that result in the accumulation of self-reactive mature naïve $\mathrm{B}$ cells in their blood. ${ }^{58}$ This autoreactive $\mathrm{B}$ cell pool is thought to be the reservoir from which disease-associated autoantibodies are derived. NMO presents an opportunity to establish whether this concept is accurate, as B cells that directly produce the autoantibodies have been isolated.

Not all autoimmune diseases follow this pattern of combined central and peripheral tolerance defects. A subset of patients with MS harbor a naïve B cell 


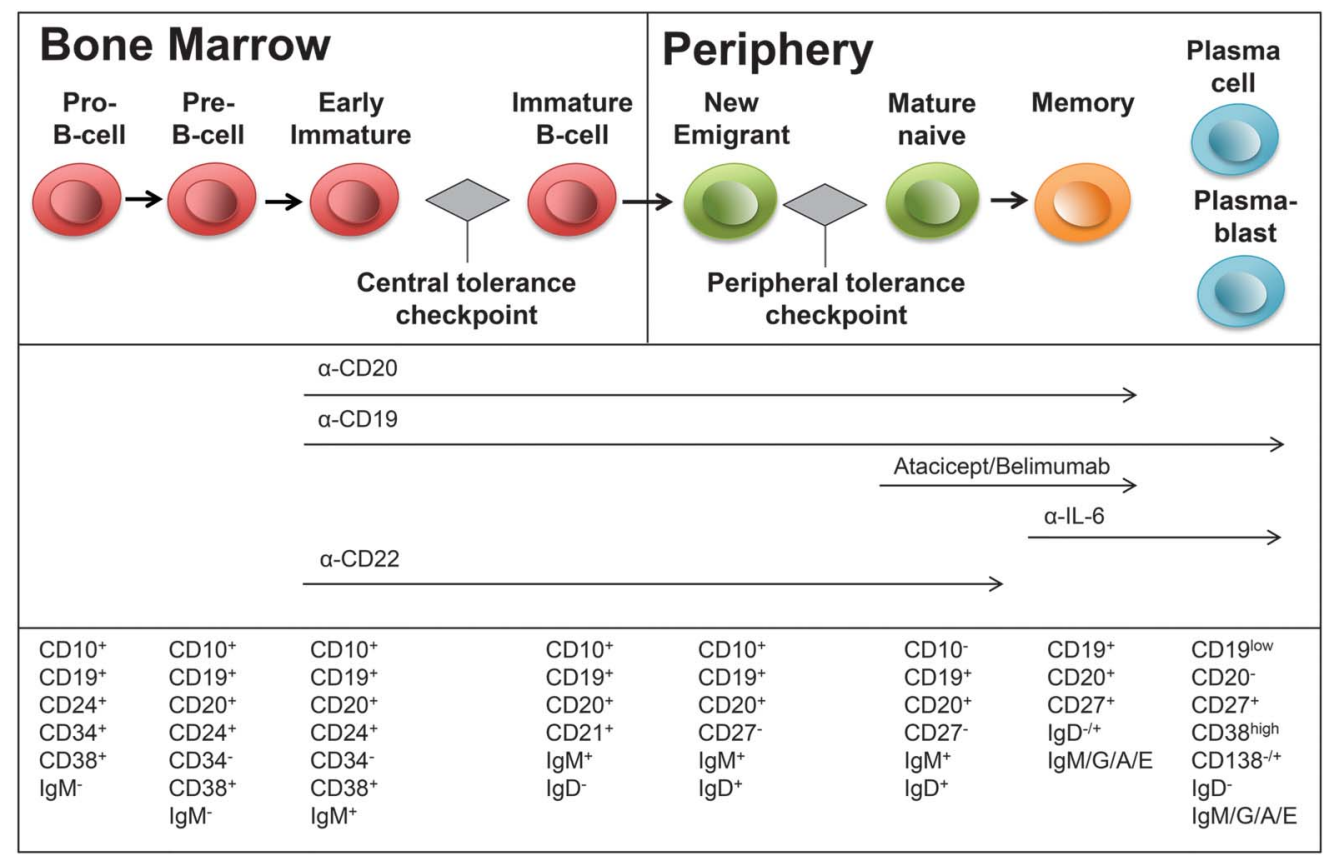

Antibodies are generated during early B cell development by random joining of immunoglobulin gene segments. The arbitrary joining is the basis for the vast diversity of the B cell repertoire needed for complete immunity, but this comes at a price: the developing $B$ cell repertoire includes autoreactive antibodies. B cell tolerance ensures that potentially detrimental autoreactive B cells are cleared from the B cell repertoire. During B cell development, autoreactive B cells are removed at 2 separate steps. In the first, a central checkpoint in the bone marrow prior to the transition to immature B cells removes the large portion of developing B cells that express polyreactive antibodies, leaving a smaller fraction of clones with low levels of polyreactivity to migrate from the bone marrow to the periphery. The second tolerance checkpoint, residing in the periphery, further counterselects autoreactive new emigrant B cells before they differentiate into mature naïve B cells. B cell lineages that may be directly affected by potential neuromyelitis optica treatment modalities are shown in the row below the schematic. Surface markers indicated in the bottom part of the schematic are not intended to be comprehensive and do not include all reported subsets. Adapted by permission from Macmillan Publishers Ltd: Nature Immunology (Meffre E, Casellas R, Nussenzweig MC. Antibody regulation of B cell development. 2000;1:379-385).

repertoire that indicates the presence of a defect exclusively in peripheral tolerance; central tolerance appears to be intact and functional. ${ }^{62}$ The similarities between $\mathrm{NMO}$ and MS raise intriguing questions regarding the role of abnormal B cell tolerance in NMO pathogenesis. Indeed, 2 studies suggest that dysfunctional B cell tolerance may contribute to the production of $\mathrm{AQP} 4-\mathrm{IgG}$ and other autoreactive peripheral $\mathrm{B}$ cells. ${ }^{4}$ Since disease activity is related to the production of AQP4 autoantibody in the majority of patients with NMO, modulation in the function of central and peripheral $\mathrm{B}$ cell checkpoints may directly influence disease activity. Recombinant antibodies produced from newly emigrant $\left(\mathrm{CD} 21^{\text {low }} \mathrm{CD} 10^{+} \mathrm{IgM}^{\text {high }} \mathrm{CD} 27^{-}\right)$and mature $\left(\mathrm{CD} 21^{+} \mathrm{CD} 10^{-} \mathrm{IgM}+\mathrm{CD} 27^{-}\right)$naïve $\mathrm{NMO} \mathrm{B}$ cells could be tested for reactivity against AQP4 and other self-antigens to determine whether the frequency of autoreactive $\mathrm{B}$ cells is greater in seropositive patients and whether diminished central or peripheral tolerance is responsible for both AQP4-specific and other autoreactivities.

B cell-depleting therapies, such as rituximab, reduce the relapse rate in NMO (table 3).
Understanding the role of both central and peripheral tolerance in the counterselection of AQP4-reactive B cells in NMO may guide administration of B celldepleting therapies. If central $\mathrm{B}$ cell tolerance is impaired in $\mathrm{NMO}$, then the production of a large population of autoreactive $B$ cells in the BM could lead to a rapid relapse of disease activity during $B$ cell reconstitution. Conversely, if only peripheral B cell tolerance is abnormal, as appears to be the case in MS, normal B cell repertoires should be established following depletion and reconstitution. Hence, understanding $\mathrm{B}$ cell tolerance in $\mathrm{NMO}$ may be critical for determining whether induction or continuous $\mathrm{B}$ cell depletion is needed to maintain treatment response. ${ }^{62}$

Anergy. B cell anergy is another mechanism that contributes to silencing humoral autoimmunity. The role of $\mathrm{B}$ cell anergy in NMO and human autoimmune disease is relatively unexplored. ${ }^{63}$ During disease relapse, anergic escape may increase the frequency of circulating AQP4$\mathrm{IgG}+$ plasmablasts and thereby increase AQP4-IgG titers. $^{18,22,34}$ In combination with central or peripheral deficiencies of B cell tolerance, anergic escape may 


\begin{tabular}{|c|c|c|}
\hline Table 3 & therapeutics in NMO & treatment pipeline \\
\hline Agent(s) & Target & Potential mechanism(s) \\
\hline $\begin{array}{l}\text { Rituximab, } \\
\text { ofatumumab, } \\
\text { ocrelizumab }\end{array}$ & $\begin{array}{l}\text { Anti-CD20-mediated } \\
\mathrm{B} \text { cell depletion }\end{array}$ & $\begin{array}{l}\text { Reduction in proinflammatory B cells; may result in } \\
\text { transient BAFF elevation }\end{array}$ \\
\hline Medi-551 & $\begin{array}{l}\text { Anti-CD19-mediated } \\
\text { B cell depletion }\end{array}$ & $\begin{array}{l}\text { Reduction in proinflammatory } B \text { cell and APC } \\
\text { numbers; may reduce regulatory B cell numbers } \\
\text { and activity }\end{array}$ \\
\hline Atacicept & $\begin{array}{l}\text { APRIL/TACI scavenger } \\
\text { receptor }\end{array}$ & $\begin{array}{l}\text { Reduction of APCs; may reduce regulatory B cell } \\
\text { numbers and activity }\end{array}$ \\
\hline Belimumab & Anti-BAFF antibody & $\begin{array}{l}\text { Reduction of APCs; may reduce regulatory B cell } \\
\text { numbers and activity }\end{array}$ \\
\hline Anti-IL-17 & Anti-IL-17 antibody & $\begin{array}{l}\text { Reduce T cell proinflammatory activity; reduce } \\
\text { CNS neutrophil recruitment; reduce B cell survival }\end{array}$ \\
\hline Anti-CD22 & $\begin{array}{l}\text { Anti-CD22-mediated } \\
\text { depletion }\end{array}$ & Reduction in anergic $B$ cells \\
\hline Tocilizumab, SA237 & $\begin{array}{l}\text { Anti-IL-6 receptor } \\
\text { antibody }\end{array}$ & $\begin{array}{l}\text { Reduction in APC survival; autoantibody } \\
\text { production; reduction in proinflammatory B cell } \\
\text { activity }\end{array}$ \\
\hline Anti-IL-5 & Anti-IL-5 antibody & $\begin{array}{l}\text { Reduction of APCs; reduction of CNS eosinophil } \\
\text { infiltration }\end{array}$ \\
\hline
\end{tabular}

Abbreviations: APC $=$ antibody-producing cell; APRIL $=$ a proliferation-inducing ligand; $\mathrm{BAFF}=\mathrm{B}$ cell-activating factor; $\mathrm{IL}=$ interleukin; $\mathrm{NMO}=$ neuromyelitis optica; $\mathrm{TACl}=$ transmembrane activator and CAML interactor.

References e-35 and e-36 at Neurology.org/nn provide a recent review of NMO treatment data. and a burgeoning array of immunotherapeutics (table 3) provide a promising environment for the development and evaluation of targeted therapeutics. As noted previously, strategies involving B cell depletion or modulation may alter multiple B cell functions, so their effects cannot easily be attributed to particular subpopulations that are solely defined by surface markers. Consequently, B cell subset analysis using multiparameter flow cytometry, cytokine profiles, and functional assays must be integrated to better understand the potential multiple biologic effects of these investigational therapies. Prospective studies incorporating high-quality biological assays in wellcharacterized patient cohorts participating in therapeutic trials with these B cell targeting experimental agents would be most informative.

\section{SUMMARY AND FUTURE DIRECTIONS Emerging} evidence suggests that $\mathrm{B}$ lineage cells may be multipurpose contributors to $\mathrm{NMO}$ spectrum disorders. AQP4-IgG is detectable in the serum and CSF of the majority of patients with $\mathrm{NMO}$ and reproduces disease-specific pathology. The contribution of $\mathrm{B}$ cells to NMO pathogenesis, however, may extend beyond the production of AQP4-IgG to include an imbalance of proinflammatory and anti-inflammatory $\mathrm{B}$ cell functions. Accumulating evidence points toward the importance of antigen presentation and cytokine secretion; however, impaired B cell tolerance and aberrant anergic silencing warrant further study. Basic and translational research, closely associated with clinical studies, should be leveraged toward defining the mechanisms of communication between $\mathrm{B}$ cells and other immune cells that drive NMO pathogenesis in order to identify novel targets for therapeutic intervention.

\section{AUTHOR CONTRIBUTIONS}

Dr. J.L. Bennett participated in the analysis, interpretation, writing, and critical review of the manuscript for important intellectual content. Dr. K.C. O'Connor participated in the analysis, interpretation, writing, and critical review of the manuscript for important intellectual content. Dr. A. Bar-Or participated in the analysis, interpretation, writing, and critical review of the manuscript for important intellectual content. Dr. S.S. Zamvil participated in the critical review of the manuscript for important intellectual content. Dr. B. Hemmer participated in the critical review of the manuscript for important intellectual content. Dr. T.F. Tedder participated in the critical review of the manuscript for important intellectual content. Dr. H.-C. von Budingen participated in the critical review of the manuscript for important intellectual content. Dr. O. Stuve participated in the critical review of the manuscript for important intellectual content. Dr. M.R. Yeaman participated in the critical review of the manuscript for important intellectual content. Dr. T.J. Smith participated in the critical review of the manuscript for important intellectual content. Dr. C. Stadelmann participated in the critical review of the manuscript for important intellectual content.

\section{ACKNOWLEDGMENT}

The authors thank The Guthy-Jackson Charitable Foundation for its support in organizing the NMO International Clinical Consortium \& Biorepository. Contributors from the Guthy-Jackson Charitable 
Foundation NMO International Clinical Consortium and Biorepository and Biorepository Oversight Committee are recognized in alphabetic order by institution: Tanuja Chitnis (Brigham and Women's Hospital and Massachusetts General Hospital, Boston, USA); Raffaele Iorio (Catholic University, Rome, Italy); Jens Würfel (Charité Universitätsmedizin, Berlin; University Medicine, Göttingen, Germany); Friedemann Paul (Charité University Medicine Berlin, Berlin, Germany); Philippe Cabre (CHRU Pierre Zobda-Quitman, Fort de France, Martinique, French West Indies); Danielle van Pelt and Rogier Hintzen (Department of Neurology, Erasmus MC, Rotterdam); Romain Marignier (Hôpital Neurologique Pierre Wertheimer, Hospices Civils de Lyon/Centre des Neurosciences de Lyon, Lyon, France); Pablo Villoslada (Hospital Clinic and Institute of Biomedical Research August Pi Sunyer (IDIBAPS), Barcelona, Spain); Michael Levy (Johns Hopkins University, Baltimore, USA); Lekha Pandit (KS Hegde Medical Academy, Nitte University, Mangalore, India); Eric Klawiter (Massachusetts General Hospital, Harvard Medical School, Boston, MA); Brian Weinshenker (Mayo Clinic, Rochester, MN, USA); Dean Wingerchuk (Mayo Clinic, Scottsdale, AZ, USA); Ho Jin Kim (National Cancer Center, Goyang-si, Gyeonggi-do, Republic of Korea); Silvia Tenembaum (National Pediatric Hospital Dr. Juan P. Garrahan, Buenos Aires, Argentina); Jacqueline Palace and Maria Isabel Leite (Oxford University Hospitals Trust, Oxford, UK); Metha Apiwattanakul (Prasat Neurological Institute Bangkok, Thailand); Simon Broadley (School of Medicine, Griffith University, Gold Coast Campus, QLD, Australia \& Department of Neurology, Gold Coast University Hospital, Southport, QLD, Australia); Naraporn Prayoonwiwat (Siriraj Hospital, Mahidol University, Bangkok, Thailand); Kerstin Hellwig (St Josef Hospital Bochum, Bochum, Germany); Ingo Kleiter (St. Josef-Hospital, Ruhr-University Bochum, Bochum, Germany); May Han (Stanford University School of Medicine, Stanford, CA, USA); Brenda Banwell (The Children's Hospital o Philadelphia, University of Pennsylvania, USA); Katja Van Herle (The Guthy Jackson Charitable Foundation, San Diego, CA, USA) Gareth John (The Mount Sinai Hospital, New York, USA); Anu Jacob (The Walton Centre NHS Foundation Trust, Liverpool, UK); Craig Hooper (Thomas Jefferson University, Philadelphia, USA); Douglas Kazutoshi Sato, Ichiro Nakashima, and Kazuo Fujihara (Tohoku University, Sendai, Japan); Denis Bichuetti (Universidade Federal de Sao Paulo, Sao Paulo, Brazil); Orhan Aktas (Universitat Dusseldorf, Dusseldorf, Germany); Jerome De Seze (University Hospital of Strasbourg, Strasbourg, France); Andre van Herle (University of California, Los Angeles, CA); Emmanuelle Waubant (University of California San Francisco, USA); Marco Lana-Peixoto (University of Minas Gerais Medical School, Belo Horizonte, Brazil); Nasrin Asgari (University of Southern Denmark, Denmark and Department of Neurology, Vejle Hospital, Denmark); Benjamin Greenberg (University of Texas Southwestern Medical Center at Dallas, Dallas, USA)

\section{STUDY FUNDING}

The Guthy-Jackson Charitable Foundation supported the organization of the NMO International Clinical Consortium \& Biorepository for the preparation of this manuscript.

\section{DISCLOSURE}

J.L. Bennett is on the editorial board for Journal of Neuro-ophthalmology, Multiple Sclerosis Journal, and Neurology: Neuroimmunology \& Neuroinflammation; holds patents for compositions and methods for the treatment of neuromyeltis optica and novel blocking monoclonal therapy for neuromyelitis optica; has consulted for EMD-Serono, Questcor Pharmaceuticals, Alnylam Pharmaceuticals, Medimmune, Abbvie, Novartis Pharmaceuticals, Chugai Pharmaceuticals, Genzyme, and Genentech; received research support from Questcor Pharmaceuticals, Novartis Pharmaceuticals, NIH, and Guthy-Jackson Foundation; holds stock in Apsara Therapeutics; and receives license fee and royalty payments for aquaporumab. K. O'Connor is on the scientific advisory board for Myasthenia Gravis Foundation of America; has received travel funding and speaker honoraria from ACTRIMS-CMSC; received speaker fees from EMD-Serono; is on the editorial board for BMC Neurology; has consulted for Scitemex; received research support from EMD-Serono, NIH, Department of Army, Nancy Davis Foundation for MS, and Myasthenia Gravis Foundation of America; and is a shareholder in Merck, Bacterin, and Sanofi. A. Bar-Or is on the scientific advisory board for Diogenix, Ono Pharmacia, Receptos, Roche, Novartis, GSK, and Guthy-Jackson Greater Good Foundation; is on the editorial board for Neurology and Clinical and Experimental Neuroimmunology; has consulted for Diogenix, Ono Pharmacia, Receptos, Roche, Novartis, and GSK; and received research support from Novartis and Genzyme-Sanofi. S.S. Zamvil received honoraria for serving on data safety monitoring boards for MS trials conducted by BioMS, Teva Pharmaceuticals, Inc., and Eli Lilly and Co.; is a member of the clinical advisory board for the Myelin Repair Foundation; is deputy editor for Neurology: Neuroimmunology \& Neuroinflammation; holds a patent for Aquaporin-4 peptides and methods for using same; received speaker honoraria from Biogen-Idec, Teva Neuroscience, and Genzyme; has consulted for Biogen-Idec, Teva Neuroscience, EMD-Serono, Genzyme, and Novartis; is on the speakers' bureau for Advanced Health Medica and Biogen-Idec; and received research support from NIH, NMSS, Guthy-Jackson Charitable Foundation, and June L. Maisin Foundation. B. Hemmer is on the advisory board for Bayer, Biogen-Idec, Roche, Novartis, Merck-Serono, Chugai, GSK, and Genentech; received travel funding and/or speaker honoraria from Bayer, Biogen-Idec, Roche, Novartis, and Merck-Serono; is on the editorial board for Archives of Neurology and Experimental Neurology; holds patents for Anti-KIR4.1 Antibody testing in MS and Genetic factors influencing the development of NABs; consulted for Gerson Lehrman Group; and received research support from Bayer, Biogen-Idec, Roche, Novartis, Merck-Serono, Metanomics, Chugai Pharmaceuticals, Protagen, and Deutsche Forschungsgemeinschaft, Bundesministerium fur Bildung und Forschung, European Community. T.F. Tedder is an editor for International Immunology and received research support from Genzyme and Guthy-Jackson Charitable Foundation. H.-C. von Büdingen is on the scientific advisory board for Novartis and Roche and received research support from Roche, Pfizer, NIH/National Institute of Neurological Disorders and Stroke, and National Multiple Sclerosis Society. O. Stuve is on the scientific advisory board for Pfizer and Sanofi-Aventis; is on the editorial board for JAMA Neurology, Therapeutic Advances in Neurological Disorders, Clinical and Experimental Immunology, and Multiple Sclerosis Journal; and received research support from Teva Pharmaceuticals, Opexa Therapeutics, and Department of Veterans Affairs. M.R. Yeaman is on the scientific advisory board for Guthy-Jackson Charitable Foundation; is an associate editor for PLoS Pathogens; holds patents for vaccines targeting drug-resistant pathogens, Immunotherapies targeting drug-resistant pathogens, Novel anti-infective biological therapeutics, Novel antiinfective small molecules, and Novel biologicals regulating programmed cell death; has consulted for Guthy-Jackson Charitable Foundation; received research support from NovaDigm Therapeutics, Metacin, United States Department of Defense, and NIH; holds stock in NovaDigm Therapeutics and Metacin; and receives fees and royalty payments from Vaccines targeting drug-resistant pathogens, NovaDigm Therapeutics, Inc.. T.J. Smith received research support from River Vision, NIH, University of South Denmark, Bell Charitable Foundation, RPB Foundation, and Guthy-Jackson Charitable Foundation. C. Stadelmann is on the scientific advisory board for Novartis Pharma $\mathrm{GmbH}$ and Teva Pharmaceutical Industries; received travel funding and speaker honoraria from Novartis, Teva, Biogen-Idec, and Bayer; is on the editorial board for Multiple Sclerosis Journal and Neurology: Neuroimmunology \& Neuroinflammation; received research support from Teva, Deutsche Forschungsgemeinschaft, Myelin Repair Foundation, and Hertie Foundation; and her spouse received support from Thyssen Research Foundation. Go to Neurology.org/nn for full disclosure forms.

Received January 7, 2015. Accepted in final form February 16, 2015.

\section{REFERENCES}

1. Wingerchuk D, Lennon V, Pittock S, Lucchinetti C, Weinshenker B. Revised diagnostic criteria for neuromyelitis optica. Neurology 2006;66:1485-1489.

2. Wingerchuk DM, Lennon VA, Lucchinetti CF, Pittock SJ, Weinshenker BG. The spectrum of neuromyelitis optica. Lancet Neurol 2007;6:805-815.

3. Waters PJ, Pittock SJ, Bennett JL, Jarius S, Weinshenker BG, Wingerchuk DM. Evaluation of 
aquaporin-4 antibody assays. Clin Exp Neuroimmunol 2014;5:290-303.

4. Pittock SJ, Lennon VA, de Seze J, et al. Neuromyelitis optica and non organ-specific autoimmunity. Arch Neurol 2008;65:78-83.

5. Bennett J, Lam C, Kalluri S, et al. Intrathecal pathogenic anti-aquaporin-4 antibodies in early neuromyelitis optica. Ann Neurol 2009;66:617-629.

6. Saadoun S, Waters P, Bell BA, Vincent A, Verkman AS, Papadopoulos MC. Intra-cerebral injection of neuromyelitis optica immunoglobulin $\mathrm{G}$ and human complement produces neuromyelitis optica lesions in mice. Brain 2010; 133:349-361.

7. Içöz S, Tüzün E, Kürtüncü M, et al. Enhanced IL-6 production in aquaporin-4 antibody positive neuromyelitis optica patients. Int J Neurosci 2010;120:71-75.

8. Uzawa A, Mori M, Arai K, et al. Cytokine and chemokine profiles in neuromyelitis optica: significance of interleukin-6. Mult Scler 2010;16:1443-1452.

9. Correale J, Fiol M. Activation of humoral immunity and eosinophils in neuromyelitis optica. Neurology 2004;63: 2363-2370.

10. Pellkofer HL, Krumbholz M, Berthele A, et al. Long-term follow-up of patients with neuromyelitis optica after repeated therapy with rituximab. Neurology 2011;76:1310-1315.

11. Matsushita T, Yanaba K, Bouaziz JD, Fujimoto $M$, Tedder TF. Regulatory B cells inhibit EAE initiation in mice while other B cells promote disease progression. J Clin Invest 2008;118:3420-3430.

12. McMillan R, Longmire RL, Yelenosky R, Lang JE, Heath V, Craddock CG. Immunoglobulin synthesis by human lymphoid tissues: normal bone marrow as a major site of IgG production. J Immunol 1972;109:1386-1394.

13. Jarius S, Paul F, Franciotta D, et al. Cerebrospinal fluid findings in aquaporin- 4 antibody positive neuromyelitis optica: results from 211 lumbar punctures. J Neurol Sci 2011;306:82-90.

14. Jarius S, Franciotta D, Paul F, et al. Cerebrospinal fluid antibodies to aquaporin- 4 in neuromyelitis optica and related disorders: frequency, origin, and diagnostic relevance. J Neuroinflammation 2010;7:52.

15. Chihara N, Aranami T, Oki S, et al. Plasmablasts as migratory IgG-producing cells in the pathogenesis of neuromyelitis optica. PLoS One 2013;8:e83036.

16. Klawiter EC, Alvarez E, Xu J, et al. NMO-IgG detected in CSF in seronegative neuromyelitis optica. Neurology 2009;72:1101-1103.

17. Radbruch A, Muehlinghaus G, Luger EO, et al. Competence and competition: the challenge of becoming a longlived plasma cell. Nat Rev Immunol 2006;6:741-750.

18. Chihara N, Aranami T, Sato W, et al. Interleukin 6 signaling promotes anti-aquaporin 4 autoantibody production from plasmablasts in neuromyelitis optica. Proc Natl Acad Sci U S A 2011;108:3701-3706.

19. Dang VD, Hilgenberg E, Ries S, Shen P, Fillatreau S. From the regulatory functions of $\mathrm{B}$ cells to the identification of cytokine-producing plasma cell subsets. Curr Opin Immunol 2014;28:77-83.

20. Owens GP, Winges KM, Ritchie AM, et al. VH4 gene segments dominate the intrathecal humoral immune response in multiple sclerosis. J Immunol 2007;179:6343-6351.

21. von Budingen HC, Kuo TC, Sirota M, et al. B cell exchange across the blood-brain barrier in multiple sclerosis. J Clin Invest 2012;122:4533-4543.
22. Jarius S, Aboul-Enein F, Waters P, et al. Antibody to aquaporin- 4 in the long-term course of neuromyelitis optica. Brain 2008;131:3072-3080.

23. Cassese G, Arce S, Hauser AE, et al. Plasma cell survival is mediated by synergistic effects of cytokines and adhesiondependent signals. J Immunol 2003;171:1684-1690.

24. Chu VT, Fröhlich A, Steinhauser G, et al. Eosinophils are required for the maintenance of plasma cells in the bone marrow. Nat Immunol 2011;12:151-159.

25. Kabashima K, Haynes NM, Xu Y, et al. Plasma cell S1P1 expression determines secondary lymphoid organ retention versus bone marrow tropism. J Exp Med 2006;203: 2683-2690.

26. Sugita K, Kabashima K, Sakabe J-I, Yoshiki R, Tanizaki H, Tokura Y. FTY720 regulates bone marrow egress of eosinophils and modulates late-phase skin reaction in mice. Am J Pathol 2010;177:1881-1887.

27. Min JH, Kim BJ, Lee KH. Development of extensive brain lesions following fingolimod (FTY720) treatment in a patient with neuromyelitis optica spectrum disorder. Mult Scler 2012;18:113-115.

28. Barnett M, Prineas J, Buckland M, Parratt J, Pollard J. Massive astrocyte destruction in neuromyelitis optica despite natalizumab therapy. Mult Scler 2012;18:108-112.

29. Kleiter I, Hellwig K, Berthele A, et al. Failure of natalizumab to prevent relapses in neuromyelitis optica. Arch Neurol 2012;69:239-245.

30. Polman $\mathrm{CH}$, O'Connor PW, Havrdova E, et al. A randomized, placebo-controlled trial of natalizumab for relapsing multiple sclerosis. N Engl J Med 2006;354:899-910.

31. Abbas M, Lalive PH, Chofflon M, Simon HU, Chizzolini C, Ribi C. Hypereosinophilia in patients with multiple sclerosis treated with natalizumab. Neurology 2011;77:1561-1564.

32. Zhang H, Verkman AS. Eosinophil pathogenicity mechanisms and therapeutics in neuromyelitis optica. J Clin Invest 2013;123:2306-2316.

33. Araki M, Matsuoka T, Miyamoto K, et al. Efficacy of the anti-IL-6 receptor antibody tocilizumab in neuromyelitis optica: a pilot study. Neurology 2014;82:1302-1306.

34. Takahashi T, Fujihara K, Nakashima I, et al. Antiaquaporin-4 antibody is involved in the pathogenesis of NMO: a study on antibody titre. Brain 2007;130:12351243.

35. Kim SH, Kim W, Li XF, Jung IJ, Kim HJ. Repeated treatment with rituximab based on the assessment of peripheral circulating memory B cells in patients with relapsing neuromyelitis optica over 2 Years. Arch Neurol 2011;68:1412-1420.

36. Nakashima I, Takahashi T, Cree BA, et al. Transient increases in anti-aquaporin-4 antibody titers following rituximab treatment in neuromyelitis optica, in association with elevated serum BAFF levels. J Clin Neurosci 2011;18:997-998.

37. Sato DK, Callegaro D, de Haidar Jorge FM, et al. Cerebrospinal fluid aquaporin-4 antibody levels in neuromyelitis optica attacks. Ann Neurol 2014;76:305-309.

38. Kitley J, Waters P, Woodhall M, et al. Neuromyelitis optica spectrum disorders with aquaporin- 4 and myelinoligodendrocyte glycoprotein antibodies: a comparative study. JAMA Neurol 2014;71:276-283.

39. Sato DK, Callegaro D, Lana-Peixoto MA, et al. Distinction between MOG antibody-positive and AQP4 antibody-positive NMO spectrum disorders. Neurology 2014;82:474-481. 
40. Saadoun S, Waters P, Owens GP, Bennett JL, Vincent A, Papadopoulos MC. Neuromyelitis optica MOG-IgG causes reversible lesions in mouse brain. Acta Neuropathol Commun 2014;2:35.

41. Molanarfi N, Schulze-Topphoff U, Weber MS, et al. MHC class II-dependent B cell APC function is required for induction of CNS autoimmunity independent of myelin-specific antibodies. J Exp Med 2013;2013:2921-2937.

42. Deenick EK, Chan A, Ma CS, et al. Follicular helper T cell differentiation requires continuous antigen presentation that is independent of unique B cell signaling. Immunity 2010;33:241-253.

43. Wang $\mathrm{HH}$, Dai YQ, Qiu W, et al. Interleukin-17secreting $\mathrm{T}$ cells in neuromyelitis optica and multiple sclerosis during relapse. J Clin Neurosci 2011;18:1313-1317.

44. Barr TA, Shen P, Brown S, et al. B cell depletion therapy ameliorates autoimmune disease through ablation of IL-6producing B cells. J Exp Med 2012;209:1001-1010.

45. Bar-Or A, Fawaz L, Fan B, et al. Abnormal B-cell cytokine responses a trigger of T-cell-mediated disease in MS? Ann Neurol 2010;67:452-461.

46. Fritz JH, Rojas OL, Simard N, et al. Acquisition of a multifunctional IgA+ plasma cell phenotype in the gut. Nature 2011;481:199-203.

47. Varrin-Doyer M, Spencer CM, Schulze-Topphoff U, et al. Aquaporin 4-specific $\mathrm{T}$ cells in neuromyelitis optica exhibit a Th17 bias and recognize Clostridium ABC transporter. Ann Neurol 2012;72:53-64.

48. Bermejo DA, Jackson SW, Gorosito-Serran M, et al. Trypanosoma cruzi trans-sialidase initiates a program independent of the transcription factors ROR $\gamma t$ and Ahr that leads to IL-17 production by activated B cells. Nat Immunol 2013;14:514-522.

49. Rauch PJ, Chudnovskiy A, Robbins CS, et al. Innate response activator $\mathrm{B}$ cells protect against microbial sepsis. Science 2012;335:597-601.

50. Kalampokis I, Yoshizaki A, Tedder TF. IL-10-producing regulatory $\mathrm{B}$ cells (B10 cells) in autoimmune disease. Arthritis Res Ther 2013;15(suppl 1):S1.

51. Collison LW, Workman CJ, Kuo TT, et al. The inhibitory cytokine IL-35 contributes to regulatory T-cell function. Nature 2007;450:566-569.

52. Shen P, Roch T, Lampropoulou V, et al. IL-35-producing $\mathrm{B}$ cells are critical regulators of immunity during autoimmune and infectious diseases. Nature 2014;507:366-370.

53. Wang RX, Yu CR, Dambuza IM, et al. Interleukin-35 induces regulatory $\mathrm{B}$-cells that suppress autoimmune disease. Nat Med 2014;20:633-641.
54. Iwata Y, Matsushita T, Horikawa M, et al. Characterization of a rare IL-10-competent B cell subset in humans that parallels mouse regulatory B10 cells. Blood 2011;117: 530-541.

55. Quan C, Yu H, Qiao J, et al. Impaired regulatory function and enhanced intrathecal activation of B cells in neuromyelitis optica: distinct from multiple sclerosis. Mult Scler 2013;19:289-298.

56. Duddy M, Niino M, Adatia F, et al. Distinct effector cytokine profiles of memory and naive human B cell subsets and implication in multiple sclerosis. J Immunol 2007;178:6092-6099.

57. Correale J, Farez M, Razzitte G. Helminth infections associated with multiple sclerosis induce regulatory B cells. Ann Neurol 2008;64:187-199.

58. Meffre E, Wardemann H. B-cell tolerance checkpoints in health and autoimmunity. Curr Opin Immunol 2008;20: 632-638.

59. Wardemann H, Yurasov S, Schaefer A, Young JW, Meffre E, Nussenzweig MC. Predominant autoantibody production by early human B cell precursors. Science 2003;301:1374-1377.

60. Menard L, Cantaert T, Chamberlain N, et al. Signaling lymphocytic activation molecule (SLAM)/SLAMassociated protein pathway regulates human B-cell tolerance. J Allergy Clin Immunol 2014;133:11491161.

61. Kinnunen T, Chamberlain N, Morbach H, et al. Accumulation of peripheral autoreactive $\mathrm{B}$ cells in the absence of functional human regulatory T cells. Blood 2013;121: 1595-1603.

62. Kinnunen T, Chamberlain N, Morbach H, et al. Specific peripheral B cell tolerance defects in patients with multiple sclerosis. J Clin Invest 2013;123:2737-2741.

63. Isnardi I, Ng YS, Menard L, et al. Complement receptor $2 / \mathrm{CD} 21^{-}$human naive $\mathrm{B}$ cells contain mostly autoreactive unresponsive clones. Blood 2010;115: 5026-5036.

64. Quach TD, Manjarrez-Orduno N, Adlowitz DG, et al. Anergic responses characterize a large fraction of human autoreactive naive $\mathrm{B}$ cells expressing low levels of surface IgM. J Immunol 2011;186:46404648.

65. Lyubchenko T, dal Porto J, Cambier JC, Holers VM. Coligation of the $\mathrm{B}$ cell receptor with complement receptor type 2 (CR2/CD21) using its natural ligand C3dg: activation without engagement of an inhibitory signaling pathway. J Immunol 2005;174:3264-3272. 


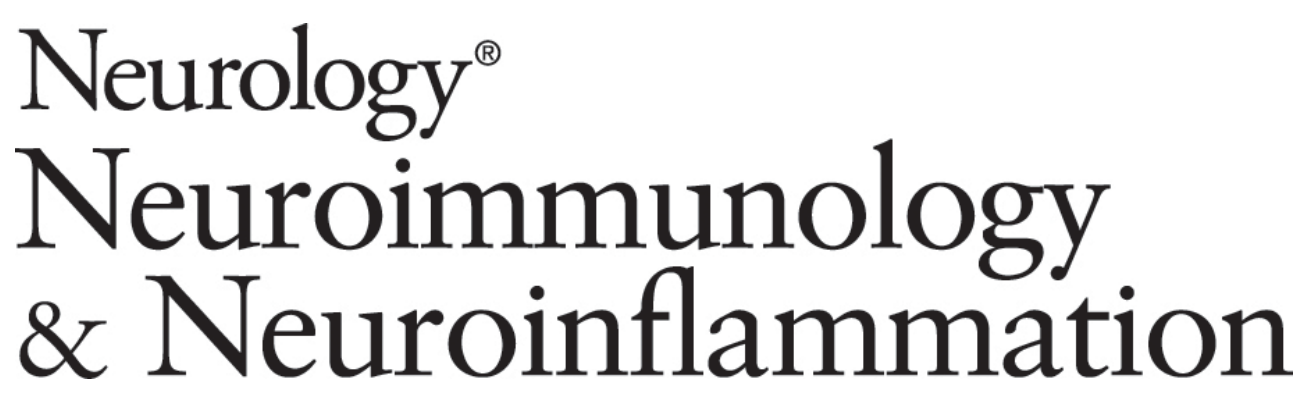

\author{
B lymphocytes in neuromyelitis optica \\ Jeffrey L. Bennett, Kevin C. O'Connor, Amit Bar-Or, et al. \\ Neurol Neuroimmunol Neuroinflamm 2015;2; \\ DOI 10.1212/NXI.0000000000000104
}

This information is current as of May 7, 2015

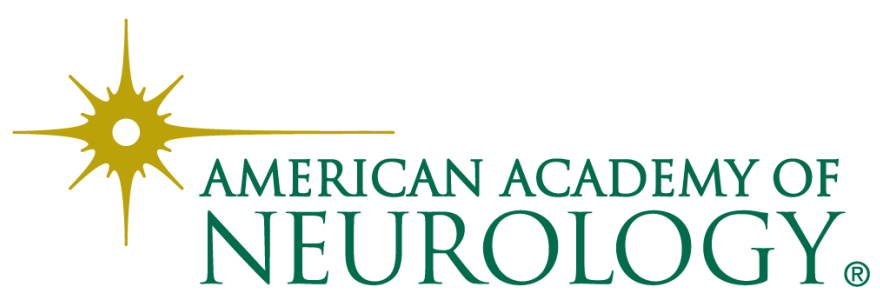




\section{Updated Information \&} Services

\section{Supplementary Material}

\section{References}

Citations

Subspecialty Collections

Permissions \& Licensing

Reprints including high resolution figures, can be found at: http://nn.neurology.org/content/2/3/e104.full.html

Supplementary material can be found at: http://nn.neurology.org/content/suppl/2015/05/07/2.3.e104.DC1

This article cites 65 articles, 14 of which you can access for free at: http://nn.neurology.org/content/2/3/e104.full.html\#\#ref-list-1

This article has been cited by 6 HighWire-hosted articles: http://nn.neurology.org/content/2/3/e104.full.html\#\#otherarticles

This article, along with others on similar topics, appears in the following collection(s):

All Immunology

http://nn.neurology.org//cgi/collection/all_immunology

Autoimmune diseases

http://nn.neurology.org//cgi/collection/autoimmune_diseases

Devic's syndrome

http://nn.neurology.org//cgi/collection/devics_syndrome

Information about reproducing this article in parts (figures,tables) or in its entirety can be found online at:

http://nn.neurology.org/misc/about.xhtml\#permissions

Information about ordering reprints can be found online: http://nn.neurology.org/misc/addir.xhtml\#reprintsus

Neurol Neuroimmunol Neuroinflamm is an official journal of the American Academy of Neurology.

Published since April 2014, it is an open-access, online-only, continuous publication journal. Copyright $\odot$ 2015 American Academy of Neurology. All rights reserved. Online ISSN: 2332-7812.

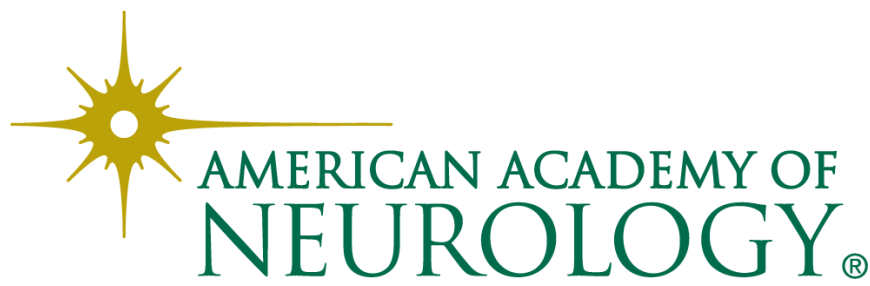

